\title{
Genome-wide microarray analysis of Atlantic cod (Gadus morhua) oocyte and embryo
}

\author{
Adrijana Škugor ${ }^{1,2}$, Aleksei Krasnov ${ }^{1 *}$ and Øivind Andersen ${ }^{1,2}$
}

\begin{abstract}
Background: Regulation of gene expression plays a central role in embryonic development. Early stages are controlled by gametic transcripts, which are subsequently substituted with transcripts from the genome of the zygote. Transcriptomic analyses provide an efficient approach to explore the temporal gene expression profiles in embryos and to search for the developmental regulators. We report a study of early Atlantic cod development that used a genome-wide oligonucleotide microarray to examine the composition and putative roles of polyadenylated transcripts.
\end{abstract}

Results: The analyses were carried out in unfertilized oocytes, newly fertilized oocytes and embryos at the stages of mid-blastula transition and segmentation. Numerous genes transcribed in oocytes are involved in multiple aspects of cell maintenance and protection, including metabolism, signal perception and transduction, RNA processing, cell cycle, defense against pathogens and DNA damage. Transcripts found in unfertilized oocytes also encoded a large number of proteins implicated in cell adherence, tight junction and focal adhesion, suggesting high complexity in terms of structure and cellular interactions in embryos prior to midblastula transition (MBT). Prezygotic transcripts included multiple regulators that are most likely involved in developmental processes that take place long after fertilization, such as components of ErbB, hedgehog, notch, retinoid, TGFb, VEGF and Wnt signaling pathways, as well as transcripts involved in the development of nervous system. The major event of MBT was the activation of a large group of histones and other genes that modify chromatin structure preceding massive gene expression changes. A hallmark of events observed during segmentation was the induction of multiple transcription factors, including a large group of homeobox proteins in pace with decay of a large fraction of maternal transcripts. Microarray analyses detected a suite of master developmental regulators that control differentiation and maintenance of diverse cell lineages.

Conclusions: Transcriptome profiling of the early stages in Atlantic cod revealed the presence of transcripts involved in patterning and development of tissues and organs long before activation of the zygotic genome. The switch from maternal to zygotic developmental programs is associated with large-scale modification of chromosomes.

Keywords: Atlantic cod, Oocyte, Embryo, Development, Microarray

\section{Background}

Early ontogeny is associated with dramatic gene expression changes that underlie and determine the developmental processes. Transcription terminates by the end of oogenesis when the maturing oocyte is arrested in the metaphase of its second meiotic division [1,2]. The oocyte is loaded with maternal mRNAs and proteins that control the cell maintenance and fate and the formation of the

\footnotetext{
* Correspondence: aleksei.krasnov@nofima.no

'Nofima, Osloveien 1, N-1432 Ås, Norway

Full list of author information is available at the end of the article
}

body plan prior to the onset of zygotic genome expression $[3,4]$. Important transcripts can be also contributed by sperm cell, as was recently shown in Drosophila and mammals $[5,6]$. Today, it is generally thought that the combination of determinants deposited by the mother during oogenesis and the inductive signals between different cells trigger the specification of different cell lineages during development of the embryo $[7,8]$. Maternal to zygotic transition (MZT) is the key event during embryogenesis marked by the switch of control from the maternal and possibly paternal transcripts to the newly synthesized 
embryonic gene products [9-11]. Degradation of maternal transcripts and zygotic genome activation is characterized by striking changes in the transcriptome profiles. MZT timing is species-specific according to the extent and form of maternal contributions and generally occurs earlier in mammals [12-15] compared to fish, Drosophila and Xenopus [16-19]. In a number of animal species, MZT roughly coincides with the mid-blastula transition (MBT) [20] when cells become motile and divide asynchronously. The three germ layers and the body plan of the mature organism are established during gastrulation, and the period is characterized by extensive cell movements and intracellular communications $[21,22]$. During the following segmentation stage major events in the formation of tissues and organs take place.

Knowledge of the genetic networks controlling embryogenesis has been obtained principally by mutagenesis screens in model species. Multiple mutations affecting embryonic development have been induced by chemical and insertional mutagenesis resulting in the identification of genes with important roles in development in Drosophila [23-25]. Similarly, large-scale genetic screens in zebrafish have enhanced the overall understanding of critical steps and pathways during embryogenesis, and forward genetics revealed a number of developmentally regulated genes [26-28]. Despite high power, this research strategy encounters limitations because only indispensable genes whose loss cannot be compensated by functionally related genes are found, leaving many important actors undetected. A complementary approach is transcriptome profiling that reveals genes with characteristic temporal expression patterns. The completion of the Atlantic cod whole-genome sequencing project [29] enabled the development of novel tools for gene expression profiling of this ecologically and commercially important marine species sustaining wild fisheries and aquaculture. DNA microarrays are used for analyses of polyadenylated mRNA and a transcriptome study of Atlantic cod embryogenesis using a cDNA microarray was recently reported [30]. We present herein the use of the Atlantic cod genome-wide oligonucleotide microarray for investigation of transcriptome changes associated with the key events of early development from unfertilized oocytes to late somitogenesis with focus on changes during MZT. Contribution of transcripts with different temporal profiles in diverse processes associated with maintenance and development was assessed and compared.

\section{Results}

\section{An overview of oocyte and embryo transcriptome}

The microarray analyses of polyadenylated mRNA included four developmental stages: unfertilized oocytes (UFO), oocytes collected at 2 hours post fertilization (2hpf), the midblastula transition (MBT) and segmentation (SGM). The features that showed over 2-fold difference in comparison with reference (adult tissues) in at least one of the analysed stages were selected. These genes were categorized as prezygotic (high expression in UFO) and zygotic (activation after fertilization), and further divided in seven subgroups based on the decreased or increased abundance at the specific stages (Figure 1, Table 1, Additional file 1). Most prezygotic transcripts maintained relatively stable levels either within the whole period examined or until SGM. A small number of transcripts decreased or increased abundance shortly after fertilization. The origin of the transcripts detected at the $2 \mathrm{hpf}$ is uncertain, but the zygote formation in Atlantic cod occurs approximately at 5 hpf [31]. Therefore, most if not all these transcripts identified at $2 \mathrm{hpf}$ most likely should be ascribed to the sperm cell. Genes activated at MBT and SGM comprised respectively $17.2 \%$ and $80.4 \%$ of all zygotic genes.

\section{Metabolism, cell maintenance, proliferation and protection}

Genes with metabolic roles comprised a large part of the developmentally regulated genes. Functional groups

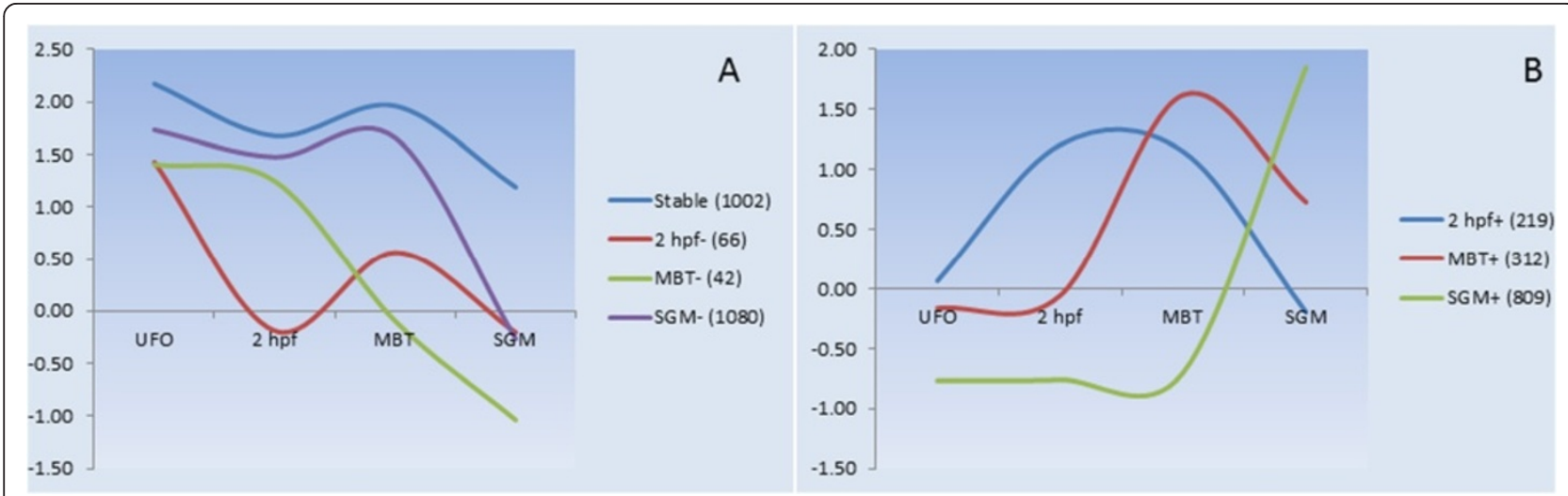

Figure 1 Developmental profiles of polyadenylated mRNA. Transcripts were categorized as prezygotic (A) or zygotic (B) and divided into subgroups as explained in Methods. Data are mean $\log _{2}$-expression ratio, the numbers of features are in parentheses. 
Table 1 Division of genes in groups by temporal expression profiles

\begin{tabular}{ll}
\hline Groups & Criteria \\
\hline Prezygotic & $\log 2-E R>0.8$ in UFO \\
Prezygotic 2 hpf- & $\log 2-$ ER $<0.3$ in 2 hpf \\
Prezygotic MBT- & $\log 2-E R<0.3$ in MBT \\
Prezygotic SGM- & $\log 2-E R<0.3$ in SGM \\
Prezygotic stable & The rest prezygotic \\
Zygotic & $\log 2-E R<0.8$ in UFO \\
Zygotic 2 hpf+ & $\log 2-E R>0.8$ in 2 hpf \\
Zygotic MBT+ & $\log 2-E R>0.8$ in MBT \\
Zygotic SGM+ & $\log 2-E R>0.8$ in SGM \\
\hline
\end{tabular}

involved in degradation of proteins and RNA were represented almost exclusively by prezygotic transcripts that suggested a profound reconstruction of the cellular machinery (Figure 2A). This was in line with zygotic activation of multiple genes encoding components of the key cellular organelles and structures: cell surface, ribosomes and microsomes with the greatest changes observed in the endoplasmic reticulum. Proteins of cytoskeleton, mitochondria and lysosomes were predominantly dependent on maternal transcripts, as well as signalling pathways controlling metabolic processes. The greatest developmental regulation was seen in the pathways of lipid and cholesterol metabolism and PPAR signalling; a sharp induction at SGM was shown by a suite of apolipoproteins (Figure 2B). Proteins involved in cell cycle and apoptosis were encoded predominantly by the maternal transcripts. $C d c 25 B$, which induces mitosis by promoting $\mathrm{G} 2 / \mathrm{M}$ phase progression, was abundant during the early stages followed by gradual decreasing levels towards the SGM. Consistently, the elimination of $c d c 25 B$ transcripts occurs by the end of the MZT in vertebrate and invertebrate species [32,33]. Other maternal mitotic regulators included cyclins and retinoblastoma-associated protein, one of the key factors that controls the entry into cell cycle. Genes encoding the mitotic checkpoint serine/threonine kinase bub1 ensuring correct chromosomal segregation during the cell division and the wee1-like protein kinase regulating DNA replication prior to mitosis were expressed until MBT and are likely to be involved in securing the integrity of the genome prior to cell division [34]. Several cell cycle related genes were found at $2 \mathrm{hpf}$, including centromere protein J, which participates in centriole duplication [35], and the positive cell cycle regulator smad nuclear interacting protein [36]. The negative regulator, cyclin-dependent kinase inhibitor $1 C$ was induced at MBT in concordance with reduction of cell proliferation.

Early fish embryos possess a multifaceted defence system. A suite of immune genes was expressed at high levels already in UFO. This group included complement components, cytokines, chemokines and their receptors, $I F N$ and TNF-related genes, together with three negative regulators of immunity from the SOCS family. Several immune genes including myeloperoxidase were activated during SGM. While protection from DNA damage was driven mainly by the maternal transcripts, responses to oxidative stress were switched on later, and seven of eight genes involved in regulation of redox homeostasis were induced during SGM (Figure 2C). Marked developmental regulation was shown by glutathione peroxidases and oxidation resistance protein coding genes.

\section{Cell-to-cell and cell-to-extracellular matrix (ECM) interactions}

The maternal transcripts were predominant among cell adhesion molecules and their input was high in other functional groups and pathways implicated in cell contacts and interactions (Figure 3A). Abundance of transcripts for cadherins (11 genes), claudins-12 and 14, and gap junction proteins was high in UFO and decreased sharply at SGM (Figure 3B). This stage was also marked with massive rearrangement of the extracellular space. Expression of two genes encoding the extracellular proteins, lens intrinsic membrane protein 2.3 and collagen $X X V$, was highly specific for oocytes, and the latter showed 227-fold greater abundance in comparison with adult tissues and remained highly abundant until SGM (Figure 3B). These proteins are scarcely explored and it is unknown whether they are required for the oocyte maturation or embryonic development. Late activation of decorin, laminin beta 1 and collagen type $I V$ witnessed increased complexity and mechanical strength of the extracellular structures (Figure 3B). Up-regulation of collagen degrading matrix metalloproteinase 13 was probably required for remodeling of extracellular matrix. High induction was shown by four genes for keratin 12 that is commonly located in epithelium being involved in interactions between cells and ECM.

\section{Transcriptional repression/activation and chromosomal remodeling}

The UFO transcriptome encoded proteins involved in mRNA processing, some of which showed highly specific expression in oocytes. For example U2 small nuclear ribonucleoprotein B displayed 69-fold higher levels compared to adult tissues (Figure 4A). The maternal transcripts of RNA helicase DDX18 encode a protein taking part in spliceosome assembly suggesting that the regulation of mRNA splicing and processing continues even after arrest of transcription in oocytes and early embryos. Transcription repressors and activators seemed to be associated with male and female gametes. UFO included several histone-lysine $N$-methyltransferases $H 3$, which have been implicated in transcriptional gene 


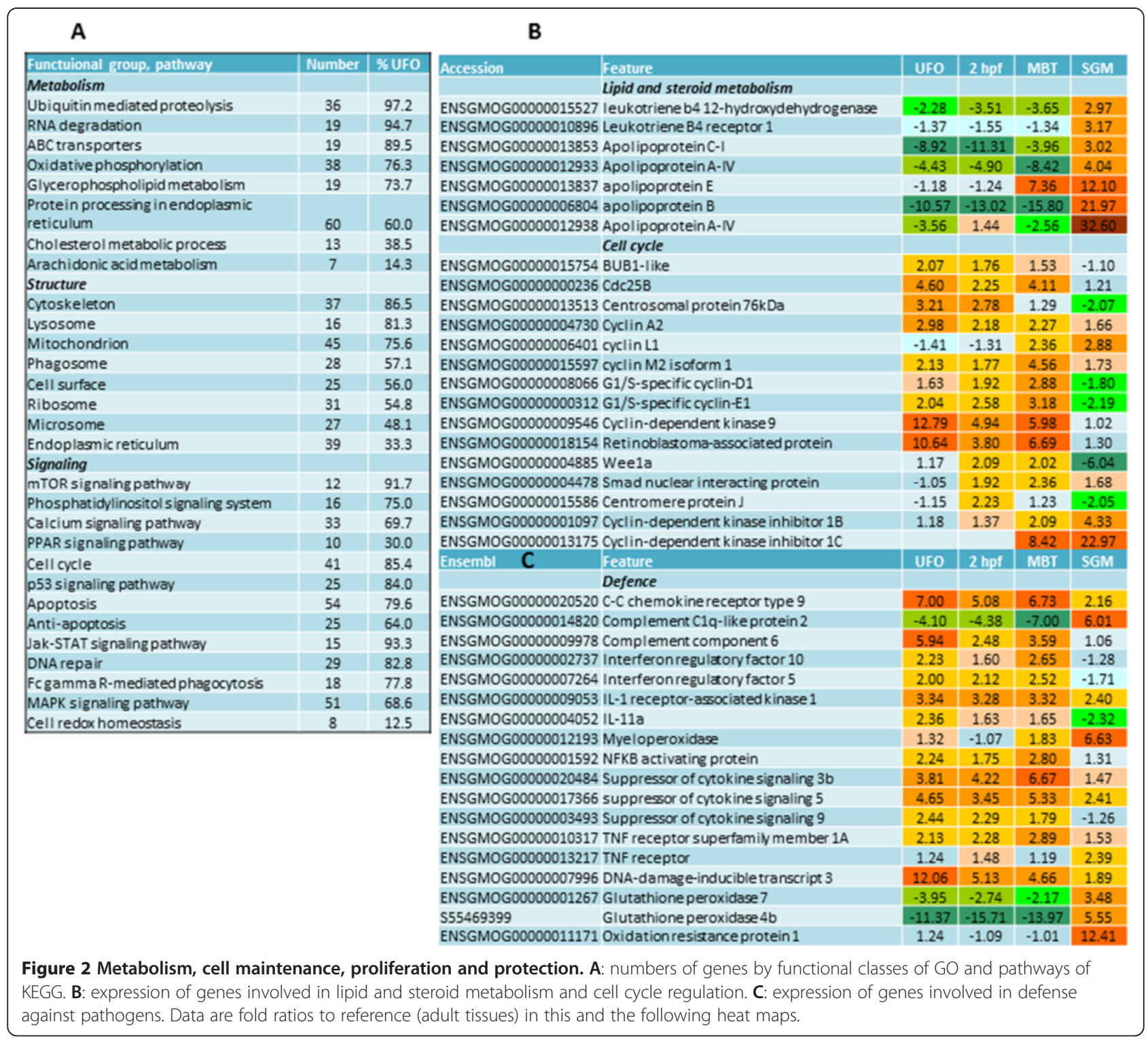

\section{A}

\begin{tabular}{|l|c|c|}
\hline Functuional group, pathway & Number & \% UFO \\
\hline Cell adhesion molecules (CAMs) & 24 & 83.3 \\
\hline Adherens junction & 38 & 68.4 \\
\hline Tight junction & 49 & 67.3 \\
\hline Extracellular space & 48 & 60.4 \\
\hline Focal adhesion & 56 & 58.9 \\
\hline Gap junction & 21 & 57.1 \\
\hline ECM-receptor interaction & 26 & 38.5 \\
\hline
\end{tabular}

Figure 3 Cell-to-cell interactions and ECM. A: numbers of genes by functional groups and pathways involved in regulation of communication

Figure $\mathbf{3}$ Cell-to-cell interactions and ECM. A: numbers of genes by functional groups and pathways involved in regulation of commur
and contacts between cells. B: expression patterns of genes coding for proteins involved in cell adhesion and cell-to-ECM interactions.

\section{B}

\begin{tabular}{|c|c|c|c|c|c|}
\hline Accession & Feature & UFO & $2 \mathrm{hpf}$ & MBT & SGM \\
\hline ENSGMOG00000002359 & Epithelial cadherin & 6.44 & 2.82 & 4.89 & 1.72 \\
\hline ENSGMOG00000015795 & Gap junction beta- 6 protein & 3.44 & 4.36 & 2.66 & -3.47 \\
\hline ENSGMOG00000017444 & Gap junction $C \times 32.2$ protein & 4.29 & 2.86 & 3.88 & -1.03 \\
\hline ENSGMOG00000007024 & Claudin 14 & 20.11 & 9.47 & 10.50 & 1.79 \\
\hline ENSGMOG00000008052 & Claudin 12 & 3.48 & 2.27 & 2.57 & 1.08 \\
\hline ENSGMOG00000004552 & $\begin{array}{l}\text { Chondroitin beta-14- } \mathrm{N} \text { - } \\
\text { acetylgalactosaminyltransferase } 2\end{array}$ & 5.19 & 4.11 & 3.92 & 1.34 \\
\hline ENSGMOG00000010361 & Lens intrinsicmembrane protein 2.3 & 38.15 & 7.25 & 7.82 & 5.32 \\
\hline ENSGMOG00000010008 & Collagen alpha-1(XXV) chain & 227.91 & 58.56 & 57.43 & 7.05 \\
\hline ENSGMOG00000019026 & Decorin & -1.17 & 1.00 & 1.79 & 29.56 \\
\hline ENSGMOG00000004625 & Collagen type IV & -2.47 & -1.73 & -3.51 & 7.32 \\
\hline ENSGMOG00000012962 & Keratin 12 & -1.06 & -1.08 & 1.14 & 50.71 \\
\hline ENSGMOG00000000769 & Laminin beta 1 & -1.62 & -3.55 & ND & 4.53 \\
\hline ENSGMOG00000017641 & Matrix metalloproteinase 13 & -2.49 & -2.63 & -3.41 & 9.68 \\
\hline
\end{tabular}

ENSGMOG00000004552 acetylgalactosaminyltransferase 2

ENSGMOG00000010008 Collagen alpha-1(XXV) chain

ENSGMOG000000004625 Collagen type IV

ENSGMOG00000012962 Keratin 12

ENSGMOG00000000769 Laminin beta 1 


\begin{tabular}{|c|c|c|c|c|c|c|c|}
\hline \multicolumn{3}{|l|}{ A } & \multicolumn{5}{|c|}{ B } \\
\hline Accession & Feature & UFO & $2 \mathrm{hpf}$ & MBT & SGM & Type & Genes \\
\hline F2OB2PE0215500 & U2 small nuclear ribonucleoprotein B & 68.83 & 12.39 & 8.84 & 1.50 & Histone H1 & 8 \\
\hline ENSGMOG00000014987 & Srrm2 protein & 12.06 & 5.33 & 5.65 & 2.02 & Histone H2A & 13 \\
\hline ENSGMOG00000003846 & Histone-lysine $\mathrm{N}$-methyltransferase $\mathrm{H} 3$ & 19.43 & 6.74 & 6.61 & 1.11 & Histone $\mathrm{H} 2 \mathrm{~B}$ & 12 \\
\hline ENSGMOG00000013774 & Histone-lysine $\mathrm{N}$-methyltransferase NSD2 & 3.49 & 2.86 & 2.82 & 1.27 & Histone $\mathrm{H} 3$ & 10 \\
\hline ENSGMOG000000009831 & Histone-lysine N-methyltransferase SETD1B-A & 3.09 & 2.47 & 3.50 & 1.22 & Histone H4 & 23 \\
\hline ENSGMOG000000009290 & Bromodomain containing $3 \mathrm{~b}$ & 3.40 & 2.68 & 2.97 & 1.83 & & \\
\hline$\$ 41418527$ & ATP-dependent RNA helicase DDX18 & 11.23 & 6.88 & 4.94 & -1.08 & & \\
\hline ENSGMOG000000002747 & Remodeling and spacing factor 1 & 8.36 & 2.53 & 3.19 & 1.17 & & \\
\hline ENSGMOG00000012758 & Sex comb on midleg family 4 & 17.10 & 5.67 & 3.01 & 1.35 & & \\
\hline ENSGMOG000000008222 & Sex comb on midleg-like 2 & 4.92 & 4.53 & 4.90 & 1.82 & & \\
\hline ENSGMOG00000001447 & Histone deacetylase 11 & -1.35 & -1.45 & -1.46 & 2.90 & & \\
\hline ENSGMOG000000015722 & Chromodomain-helicase-DNA-binding protein 8 & 1.39 & 1.24 & 1.23 & 2.27 & & \\
\hline ENSGMOG00000001770 & PWWP domain containing 2 isoform 1 & 1.24 & 2.48 & 2.00 & 1.03 & & \\
\hline ENSGMOG000000009288 & Mbt domain containing 1 & 1.06 & 2.75 & 2.64 & 1.97 & & \\
\hline ENSGMOG000000010060 & High mobility group protein B2 & -1.23 & -2.16 & 1.01 & 3.37 & & \\
\hline $\mathrm{Acc}_{\text {ssion }}$ & Feature & UFO & $2 \mathrm{hpf}$ & MBT & SGM & & \\
\hline ENSGMOG00000004374 & Histone $\mathrm{H} 1$ & 2.48 & 1.44 & 10.32 & 8.36 & & \\
\hline ENSGMOGOOOOOOO19745 & Histone $\mathrm{H} 1$ & -1.16 & -1.19 & 10.44 & 6.57 & & \\
\hline ENSGMOG000000002829 & Histone $\mathrm{H} 1$ & -4.21 & -5.06 & 4.94 & 2.97 & & \\
\hline ENSGMOG00000003292 & Histone $\mathrm{H} 2 \mathrm{~A}$ & 2.29 & 1.42 & 2.95 & 1.10 & & \\
\hline ENSGMOG000000019713 & Histone $\mathrm{H} 2 \mathrm{~A}$ & 1.13 & 1.09 & 3.16 & 1.29 & & \\
\hline ENSGMOG00000009971 & Histone $\mathrm{H} 2 \mathrm{~B}$ & 2.31 & 1.82 & 4.45 & 1.19 & & \\
\hline ENSGMOG000000020409 & Histone $\mathrm{H} 2 \mathrm{~B}$ & 1.46 & 1.20 & 3.94 & 1.22 & & \\
\hline ENSGMOG00000019966 & Histone $\mathrm{H} 2 \mathrm{~B}$ & 1.22 & 1.13 & 2.29 & -1.30 & & \\
\hline ENSGMOG00000019866 & Histone $\mathrm{H} 3.2$ & 1.89 & 1.76 & 3.42 & 1.28 & & \\
\hline ENSGMOG000000020016 & Histone H3.2 & 1.16 & 1.36 & 2.65 & 1.22 & & \\
\hline ENSGMOG00000019709 & Histone $\mathrm{H} 3.2$ & 1.00 & 1.18 & 2.28 & -1.09 & & \\
\hline ENSGMOG00000020434 & Histone $\mathrm{H} 4$ & 2.01 & 1.24 & 4.22 & 1.16 & & \\
\hline ENSGMOG00000019712 & Histone $\mathrm{H} 4$ & 1.23 & -1.18 & 4.60 & 1.30 & & \\
\hline
\end{tabular}

silencing, heterochromatin assembly and DNA methylation [37]. UFO transcripts also encoded components of the polycomb repressive complex contributing to the formation of silent chromatin. Sex-comb on midleg-like proteins are required to maintain the transcriptionally repressive state of homeotic genes throughout the development [38]. Further, the transcriptional repressors remodeling and spacing factor 1 (rsf1) and mbt domain containing 1 [39] were present in unfertilized and fertilized oocytes, respectively. A maternally supplied coactivator bromodomain containing 2 (brd2) [40,41] can be important for the early embryo cell cycle control. Fertilized oocytes contained transcripts for a protein involved in DNA methylation (PWWP domain containing 2 isoform 1). Though a number of genes related to chromosome maintenance and remodeling were present among prezygotic transcripts, major changes took place at MBT and a large fraction of the activated genes encoded histones (66 genes) (Figure 4B). Histone modifications and changes of chromatin architecture enable the formation of transcriptionally active euchromatin in order for zygotic gene expression to take place $[20,42]$. Although some of the transcripts coding for histones $\mathrm{H} 1, \mathrm{H} 2 \mathrm{~A}, \mathrm{H} 2 \mathrm{~B}, \mathrm{H} 3$ and $\mathrm{H} 4$ were present at relatively high levels already in oocytes, most of them markedly increased abundance at MBT and many had biphasic profiles (Figure 4C). Several genes involved in nucleosome and chromatin remodeling, including chromodomain helicase DNA binding protein 8 , histone deacetylase 11 and high mobility group protein $b 2$ showed highest expression at SGM (Figure 4A).

\section{Regulation of early cellular differentiation and signaling}

Many developmentally regulated genes belong to pathways with crucial roles in embryonic development (Figure 5A). A large part of these genes are transcription factors with different temporal expression profiles (Figure 5B). Transcripts for jun- $B$ that controls differentiation of diverse cell lineages [43,44], pair box protein 7 and AP-2 involved in formation of eye, limb, neural and cardiac development [45] were highly abundant in oocytes. UFO also included transcripts for proteins that play important parts in development of heart (myogenic 


\begin{tabular}{|c|c|c|c|c|c|c|c|c|}
\hline \multicolumn{4}{|l|}{ A } & \multicolumn{3}{|l|}{$\mathrm{C}$} & & \\
\hline \multicolumn{2}{|l|}{ Functuional group, pathway } & Number & UFO & \multicolumn{2}{|l|}{ Domain } & UFO & ZGT & Ratio \\
\hline \multicolumn{2}{|c|}{ Melanogenesis } & 26 & 0.77 & \multicolumn{2}{|l|}{ Zinc finger } & 42 & 3 & 0.93 \\
\hline \multicolumn{2}{|c|}{ Nervous system development } & 16 & 0.69 & \multicolumn{2}{|c|}{ Forkhead } & 9 & 4 & 0.69 \\
\hline \multicolumn{2}{|c|}{ Hedgehog signaling pathway } & 13 & 0.85 & \multicolumn{2}{|c|}{ Homeodomain } & 7 & 19 & 0.27 \\
\hline \multicolumn{2}{|c|}{ Neuroactive ligand-receptor interaction } & 30 & 0.83 & & & & & \\
\hline \multicolumn{2}{|c|}{ Wnt signaling pathway } & 35 & 0.80 & & & & & \\
\hline \multicolumn{2}{|c|}{ Transforming growth factor beta signaling } & 10 & 0.80 & & & & & \\
\hline \multicolumn{2}{|c|}{ ErbB signaling pathway } & 21 & 0.76 & & & & & \\
\hline \multicolumn{2}{|l|}{ TGF-beta signaling pathway } & 27 & 0.74 & & & & & \\
\hline \multicolumn{2}{|c|}{ Neurotrophin signaling pathway } & 48 & 0.73 & & & & & \\
\hline \multicolumn{2}{|c|}{ Notch signaling pathway } & 23 & 0.70 & & & & & \\
\hline \multicolumn{2}{|l|}{ VEGF signaling pathway } & 27 & 0.67 & & & & & \\
\hline \multirow[t]{2}{*}{ Accession C } & \multicolumn{3}{|c|}{ Feature } & UFO & $2 \mathrm{hpf}$ & MBT & SGM & \\
\hline & \multicolumn{3}{|c|}{ Transcription factors } & & & & & \\
\hline ENSGMOG00000009513 & \multicolumn{3}{|c|}{ AP-2 beta } & 21.44 & 9.95 & 9.41 & 1.88 & \\
\hline ENSGMOG00000009128 & \multicolumn{3}{|c|}{ Paired box protein 7} & 16.20 & 8.51 & 7.99 & 1.27 & \\
\hline ENSGMOG00000009780 & \multicolumn{3}{|c|}{ Myogenic enhancer factor $2 \mathrm{cll}$} & 12.94 & 5.32 & 8.79 & 2.71 & \\
\hline ENSGMOG00000013292 & \multicolumn{3}{|c|}{ Nuclear factor erythroid derived- 2 protein } & 5.57 & 2.55 & 2.20 & 3.12 & \\
\hline ENSGMOGO0000002596 & \multicolumn{3}{|c|}{ Jun-B } & 3.95 & 2.29 & 3.09 & 1.78 & \\
\hline ENSGMOG00000000378 & \multicolumn{3}{|l|}{ Runx2 } & 2.63 & -1.62 & 1.54 & -1.45 & \\
\hline ENSGMOG00000017411 & \multicolumn{3}{|c|}{ Kruppel-like factor 11} & 2.24 & 1.28 & 2.67 & -1.88 & \\
\hline ENSGMOG00000004696 & \multicolumn{3}{|c|}{ Zinc finger SWIM domain containing 5} & 1.05 & 2.00 & 2.96 & 2.48 & \\
\hline ENSGMOG00000010335 & Zinc finger $\mathrm{pr}$ & & & 1.00 & 2.70 & 3.34 & 4.05 & \\
\hline ENSGMOG00000010949 & Zinc finger $\mathrm{pr}$ & & & -1.17 & 2.20 & 2.25 & -1.13 & \\
\hline ENSGMOG00000011885 & Homeobox p & lopedia B & & ND & ND & 6.75 & 9.36 & \\
\hline ENSGMOG00000020190 & Sox3 & & & -1.18 & -1.23 & 6.48 & 14.55 & \\
\hline ENSGMOG00000015999 & Forkhead box & & & ND & 1.27 & 4.59 & 1.59 & \\
\hline ENSGMOG00000003232 & HES-5 & & & 1.33 & 1.44 & 1.85 & 90.31 & \\
\hline ENSGMOG00000015387 & HES-1 & & & 1.06 & 1.74 & 2.21 & 10.15 & \\
\hline ENSGMOG00000012207 & TCF3 & & & 1.06 & -1.16 & 1.29 & 7.98 & \\
\hline
\end{tabular}

enhancer factor [46]), cartilage and bone (runx2) and erythroid lineage (nuclear factor erythroid derived-2). Four transcription factors detected at $2 \mathrm{hpf}$ contained zinc finger domains. Greatest induction in SGM (90.3-fold) was shown by hes-5, a component of Notch pathway [47] and several homeodomain genes. Many identified transcription factors are unknown but include functional domains present in multiple regulators of development and interestingly, ratios between regulators with domains changed by stages (Figure $5 \mathrm{C}$ ). While the majority of zinc finger proteins were found among prezygotic transcripts, $73 \%$ of transcription factors with homeodomain were activated during SGM, while forkhead proteins occupied an intermediate position.

In addition to transcription factors, the developmentally regulated genes included transcripts for receptors and extracellular proteins assigned to Notch, TGF beta and Wnt signaling pathway (Figure 6A). Major part of them were present in oocytes and only two genes were each activated at MBT and SGM. Greatest differences from adult tissues (51- and 62-fold) were observed in frizzled $8 a$, a receptor for Wnt proteins, and dorsalventral patterning tolloid-like protein. Dorsoventral patterning is also regulated by two genes from TGF pathway: follistatin and noggin [48]. Maternal transcripts encoded three proteins from Smad family, which transmit signals from TGF. Notch are transmembrane proteins that bind jagged ligands controlling differentiation by receiving signals through cell to cell contacts, while deltex is a regulator of notch signaling. $\mathrm{Su}(H) B$ encodes the suppressor of hairless, a key transcriptional regulator of Notch pathway. Of note is oocyte expression of genes that regulated 


\section{A}

\begin{tabular}{|c|c|}
\hline Accession & Feature \\
\hline & Notch signaling pothway \\
\hline EN SGMOG000000006156 & $\operatorname{Su}(H) B$ \\
\hline EN SGM MOG00000018944 & Protein jagzed-1a \\
\hline ENSGMOG000000004933 & Notch 1 \\
\hline ENSGMOGOOCO00008283 & Dettex-3-like \\
\hline \multirow[t]{2}{*}{ ENSGMOGO0000020030 } & Notch-regul ated protein A \\
\hline & TGF beta signoling pothway \\
\hline ENSGMO6000000007444 & $\operatorname{Smad} 2$ \\
\hline EN SGMOG000000013964 & $5 \operatorname{Smad} 4$ \\
\hline ENSGMOG00000001314 & Smad 5 \\
\hline ENS6EMO600000015999 & Forkhead box 06 \\
\hline EN S6MOG00000005614 & Forkhead domain protein \\
\hline EN S6MOG00000006669 & Iroquois $-d$ ass homeod omain protein $\mid R x-1$ \\
\hline EN S6MOG00000011663 & Cholesterol 2s hydroxylase-ike protein A \\
\hline ENSGMO600000007399 & Follistatin \\
\hline EN SGMOG00000020412 & Noggin-3 \\
\hline \multirow[t]{2}{*}{555468000} & TNF rece ptor superfamily member 5 \\
\hline & Wnt signoling pothway \\
\hline EN SGMOG600000019835 & Fízzled sa protein \\
\hline ENSGMOG00000011204 & Protein Wnt \\
\hline EN SGMOG00000019210 & Wnt-1 prote in [Oncorthychus sp.] \\
\hline ENSGMOG00000017495 & Secreted frizzled-related protein 1 \\
\hline \multirow[t]{2}{*}{ ENSGMO600000009864 } & Secreted frizzled-related protein 1 \\
\hline & Regulators \\
\hline EN SGMOG000000001034 & Dorsal-ventral patterning tolloid-like protein 1 \\
\hline EN SGMOG00000016377 & Connective tissue growth factor \\
\hline EN SGMOG000000016130 & Thyroid hormone rece ptor al pha \\
\hline EN SGMOG000000007490 & Connective tissue growth factor \\
\hline EN SGMOG000000008794 & Retinoic acid rece ptor gamma b \\
\hline EN S6MOG00000016074 & Angio-associated migrzorycell protein \\
\hline ENSGMOCO00000013168 & Anterior gradient protein 2 homolog \\
\hline
\end{tabular}

Figure 6 Expression of genes involved in regulation of embryonic development. A: receptors and extracellular proteins. B: regulators of neural system development.

\section{B}

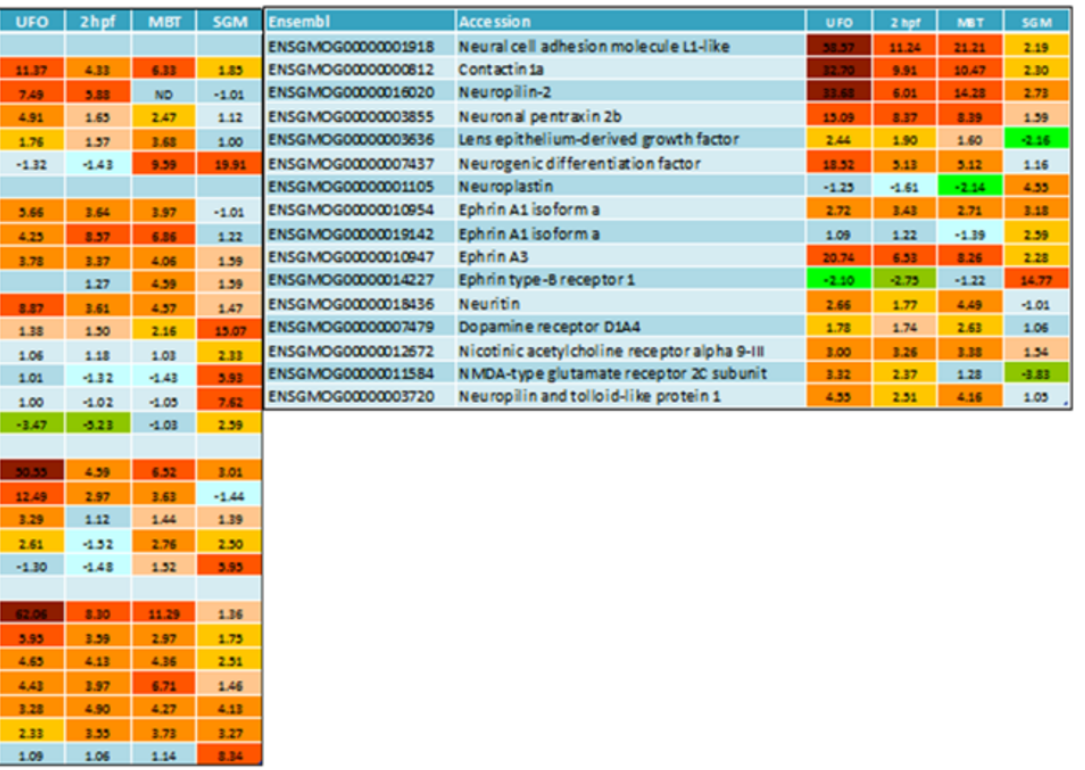

differentiation of complex structures, such as connective tissue growth factor (3 genes) and angio-associated migratory cell protein.

A suite of genes known for their roles in neurogenesis was detected already in UFO (Figure 6B). Greatest difference with adult tissues (59-, 34- and 33-fold) was shown by neural cell adhesion molecule L1-like protein (chl1) implicated in cell migration and neuronal positioning, neuropilin and contactin-1a, a neuronal cell adhesion molecule important for the formation of axon connections during the nervous system development $[49,50]$. Maternally provided transcripts also included neurogenic differentiation factors (5 genes), which are involved in neuroepithelial stem cell differentiation and neurogenesis, the synaptic protein and receptor of neurotransmitters neuronal pentraxin-1 precursor (nptx1) and two ephrins and ephrin type- $B$ receptors (4 genes), that play a crucial part in migration of axons. Interestingly, switch of ephrin and ephrin receptor isoforms took place at SGM. Maternal transcripts also encoded receptors of the dopamine and acetylcholine neurotransmitters.

\section{Master regulators of embryogenesis}

The microarray analyses revealed several genes that control stem cell fates and organ development, which were active at different stages (Figure 7). While transcript for pumilio-2 (proliferation and renewal of stem cells, germ cell development and degradation of maternal mRNAs [51]) was present in oocytes, snail homolog sna (formation and maintenance of mesoderm during embryogenesis
[52]), RNA-binding protein musashi homolog 2 (proliferation and maintenance of stem cells in the CNS [53]) were activated at MBT and SGM, respectively. Similar to zebrafish [54], MBT was marked with an onset of nanor transcription. DiGeorge syndrome critical region gene 8 may be involved in the degradation of maternal transcripts via biogenesis of microRNAs [55]. A role of microRNAs, such as miR430, in the clearance of maternal transcripts during the maternal to zygotic transition has been well documented [56,57]. Sox-2 (3 genes) is a key regulator of embryonic stem cell pluripotency [58].

\section{Validation of microarray data}

To validate microarray data, real-time qPCR was performed on eight genes: nanor, heat shock protein $70 \mathrm{kDa}$ protein 4 (hsp70), heat shock $90 \mathrm{kDa}$ protein 1 beta isoform a (hsp90ba), stress-induced phosphoprotein 1 (stip1), follistatin (fst), formin-binding protein 4 (fnbp4), keratin12 (krt12) and ikaros (ikzf) at the embryonic stages of UFO, 2hpf, MBT, 12- and 52-somites. Overall, microarrays and qPCR produced similar results (Figure 8).

\section{Discussion}

Genome sequencing enabled construction of oligonucleotide microarrays that may provide complete coverage of the polyadenylated fraction of transcriptomes; microarray analyses evaluate abundance of mature mRNA, which is capable for translation. While a genome-wide platform was used for evaluating the abundance of mature mRNA during zebrafish development [10], we report the first 


\begin{tabular}{|l|l|c|c|c|c|}
\hline Accession & Feature & UFO & 2 hpf & MBT & SGM \\
\hline ENSGMOG00000006903 & Pumilio-2 & 6.94 & 4.45 & 4.51 & 1.17 \\
\hline S41375937 & Nanor b & -4.65 & -4.53 & 19.40 & 9.54 \\
\hline ENSGMOG00000008649 & Krueppel-like factor 2 & -1.37 & -1.32 & 7.46 & 1.02 \\
\hline ENSGMOG00000019987 & Transcription factor Sox-2 & -1.92 & -1.61 & 3.84 & 13.06 \\
\hline ENSGMOG00000017838 & Musashihomolog 1 (Drosophila) & 1.29 & -1.08 & -1.31 & 7.81 \\
\hline ENSGMOG00000007715 & DiGeorge syndrome critical region gene 8 & 1.32 & 1.26 & 2.63 & 2.10 \\
\hline ENSGMOG00000000127 & Snail homologSna & 1.06 & 1.25 & 2.25 & 1.35 \\
\hline
\end{tabular}

Figure 7 Expression of selected master regulators of development.

study performed with an aquaculture fish species. The main issue was the presentation of pathways and functional groups among the transcripts displayinh different temporal profiles. High complexity of the transcriptome in unfertilized cod oocytes is consistent with similar studies in both invertebrates and vertebrates $[10,59,60]$. Maternally provided mRNA comprised the major part of prezygotic transcripts while the putative paternal contribution was small, but sperm transcripts might play important roles of in the establishing of early embryonic gene expression profiles $[5,61,62]$. Fertilized cod eggs contained a suite of transcripts for proteins involved in chromatin remodeling and regulation of transcription, cell cycle control and cellular transport. However, it is unknown whether these genes have any developmental roles. In general, maternal transcripts support basic requirements of the embryo prior to the onset of zygotic expression. Interestingly, we got evidence that processing of mRNA continues even in absence of transcription that is in line with recent report on large-scale maturation of maternal transcripts in zebrafish embryos $[57,63]$. In addition to maintenance of metabolism, cell structure and proliferation, transcripts of oocytes provide immune protection against pathogens and a suite of genes is expressed at higher level in comparison with adult tissues. Maternal transfer of complement factors and their protective roles was reported in wolffish, rainbow trout and zebrafish [64-67]. The female fish also provide offspring

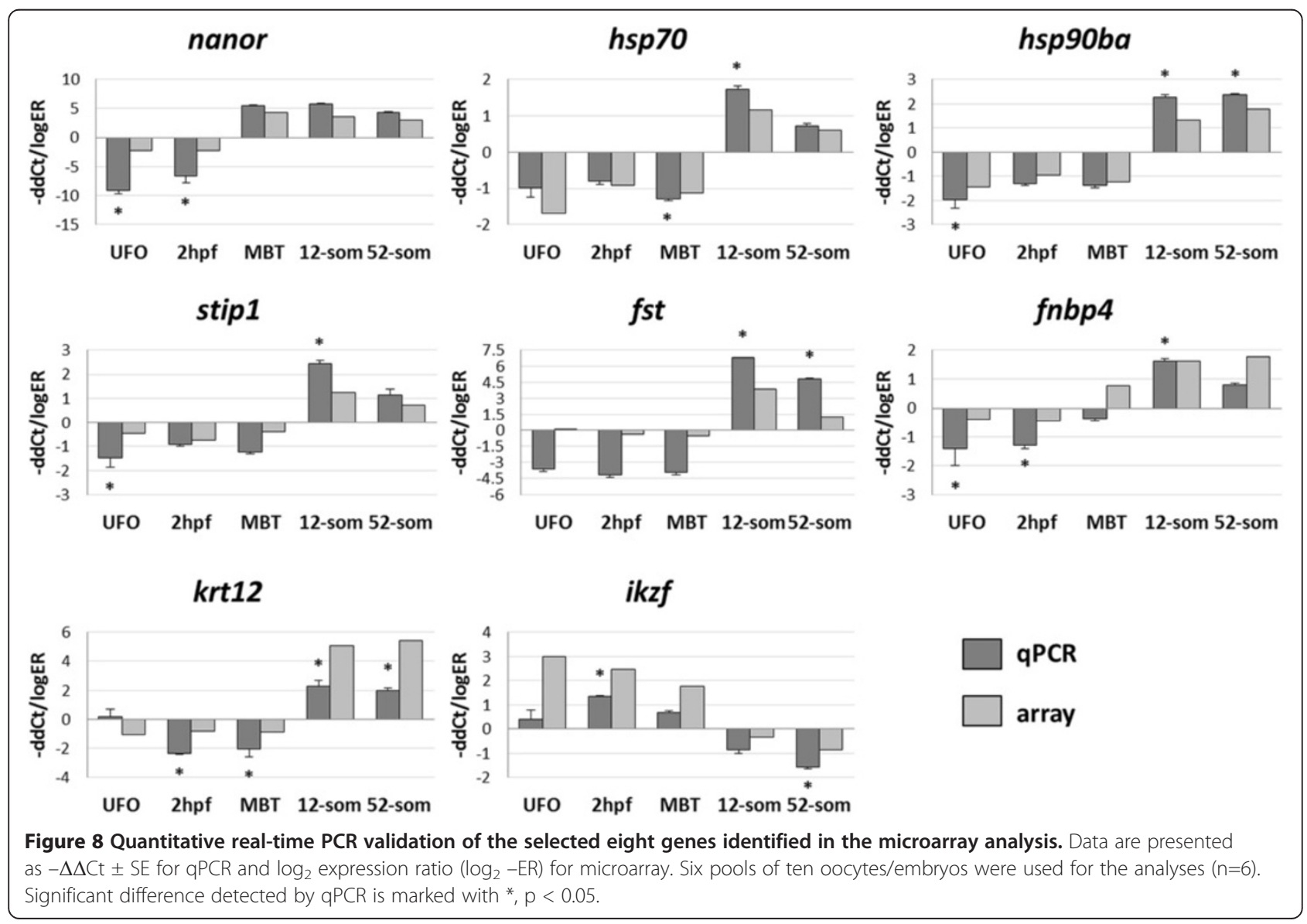


with immunoglobulins, lysozymes, protease inhibitors and different types of lectins $[68,69]$. The observed prevalence of immune genes involved in signaling suggests that embryos are capable to regulate responses to pathogens. Presentation of multiple signal transduction pathways points to active perception of external cues and complex interactions between early embryos and environment.

Differentiation presumes acquisition of specific properties by cells and increase of their heterogeneity. A large number of transcripts for proteins involved in cell contacts were abundant in UFO being eliminated at SGM. Cadherins are transmembrane cell adhesion proteins that mediate various processes during development including cellular migration and tissue organization [70]. Interestingly, this study identified a large number of cadherin paralogs that are likely involved in cell sorting and tissue morphogenesis [71]. UFO included many transcripts that can be involved in the control of processes taking place long after fertilization, such as components of Wnt, Notch, hedgehog, ErbB, TGF beta and VEGF signaling pathways and markers of specialized cell lines $[72,73]$. We also identified multiple transcripts that may regulate neurogenesis or encode proteins known as highly specific for neural tissue, in agreement with a few studies reporting maternal deposition of transcripts later expressed in the CNS (e.g. Drosophila, zebrafish and axolotl [74-76]). This finding can partly be accounted for by the bias in annotation, since a number of genes with pleiotropic functions have been studied mainly in the context of nervous system. Furthermore, some genes could change functions in course of the vertebrate evolution as demonstrated by the identification several genes known as neural specific in mammals were primarily involved in innate antiviral responses in fish $[77,78]$.

Transcriptome analyses suggested that the onset of zygotic expression is preceded by large scale modification of chromosomes. Histones comprise a major fraction of genes activated during MBT while the number of transcription factors in this group was small. The preMBT transcripts encoded several proteins that modify histones and DNA and are known as positive and negative regulators (e.g. myst2, brd2, n6amt1, rsf1, ehmt3, scml-1, 2 and 4). Transcripts coding for histone methyltransferases and members of the polycomb repressors were highly abundant in unfertilized and fertilized oocytes, but showed a decrease in expression after MBT and coincided with the chromatin remodeling prior to the activation of transcription. Preparation of transcriptional machinery to the large-scale activation of gene expression appears a major developmental event that takes place during MBT. In most studied vertebrates this period coincides with the degradation of maternal transcripts and activation of the zygotic genome which takes over the genetic control of embryogenesis [10,79]. Furthermore, accumulated studies reveal the dynamic nature of chromatin regulation and the importance of its modifications during transitions from maternal to zygotic control of development $[20,42,80]$. Our data are consistent with recent studies reporting the activation of zygotic transcription at MBT in Atlantic cod [30,81]. As large fraction of genome is transcriptionally inactive, rearrangement of chromatin is essential to provide an access of transcription factors to the cis-regulatory elements [82]. Microarray analyses are insufficient for accurate timing of the onset of transcription. Part of transcripts appear in the polyadenylated fraction due to maturation of maternal RNA [57,63]. However, given modification of chromosomes during MBT and the size of the the SGM group, it is likely that a large part of mRNA denoted as zygotic was indeed transcribed from the zygotic genome. The SGM group was complex by composition and contained numerous developmental regulators. Massive upregulation of homeobox genes at SGM is consistent with their involvement in the establishment of body plan and formation of anterior-posterior axis of the embryo [83,84]. Homeobox transcription factors and cell signaling pathways cooperate to pattern tissues and organs and to specify the fate of a variety of cell types. However, none of the functional groups and pathways was restricted to the post-MBT period and all were largely represented among UFO.

\section{Conclusion}

Transcriptome profiling of the oocytes and embryos of Atlantic cod with an aid of genome-wide microarray provided an insight in events taking place in early development and the roles of parental and zygotic transcripts. Maternal transcripts are involved in cellular metabolism, signal perception and transduction, defence, communication and contacts between cells. High representation of pathways and genes that control development suggest early cell fate specification and patterning of tissues and organs, especially of the neuronal lineage. The key event of zygotic genome activation at MBT was extensive chromatin rearrangements followed by expression of multiple developmental regulators.

\section{Methods}

\section{Ethical approval}

The study was approved by the Norwegian Animal Research Authority and conducted according to the prevailing animal welfare regulations: FOR-1996-01-15-23 (Norway), European Convention for the Protection of Vertebrate Animals used for Experimental and Other Scientific Purposes (Strasbourg, 18.III.1986) and COUNCIL DIRECTIVE of 24 November 1986 on the approximation of laws, regulations and administrative provisions of the 
Member States regarding the protection of animals used for experimental and other scientific purposes (86/609/ $\mathrm{EEC})$.

\section{Sample collection}

Atlantic cod eggs and embryos were obtained from farmed fish at the National Cod Breeding Centre (Kraknes, Tromsø, Norway). Eggs were hand stripped, fertilized in vitro and transferred to seawater rearing tanks at an average temperature of $4.5^{\circ} \mathrm{C}$ and $100 \%$ oxygen saturation. The following stages were selected for analyses: 1) unfertilized (UFO) and 2) newly fertilized oocytes, $2 \mathrm{hpf}$ and embryos at 3) mid-blastula (MBT), 4) 12 somites and 5) 52 somites (end of somitogenesis). Embryonic stages were determined based on description of Atlantic cod development with precise timing [85]. Tissues from adult male and female cod were used as a reference in the microarray analyses. Eggs and tissue samples were stored in RNAlater (Ambion, Austin, Texas, USA).

\section{RNA extraction}

Total RNA was extracted from Atlantic cod eggs and tissues using TRIzol (Life Technologies) and PureLinkTM RNA mini kit (Ambion, Austin, Texas, USA). For each developmental stage, 10 oocytes/embryos were pooled for the analyses. On-column DNase treatment was performed using PureLinkTM DNase (Life Technologies) in order to remove traces of DNA and impurities. The concentration was analyzed by NanoDrop ND-1000 spectrophotometer (Thermo Fisher Scientific, Wilmington, USA). The total RNA quality was assessed with Agilent 2100 Bioanalyzer (Agilent 2100 Bioanalyzer, Agilent Technologies, Waldbronn, Germany) and only the samples of high quality $(\mathrm{RIN} \geq 8)$ were selected for analysis.

\section{Microarray analyses}

The Nofima's Atlantic cod oligonucleotide microarray (ACIQ-2) produced by Agilent Technologies in the $4 \times$ $44 \mathrm{k}$ format included 60 -mer probes to the unique

Table 2 Primer list for real-time qPCR

\begin{tabular}{|c|c|c|c|}
\hline Gene name & Gene symbol & Sequence $\left(5^{\prime}-3^{\prime}\right)$ & Product length, bp \\
\hline \multirow[t]{2}{*}{ nanor } & nanor & ATCCAATACCCAACGGTTCA & 92 \\
\hline & & GCGATGAAATGGCTGAATCT & \\
\hline \multirow[t]{2}{*}{ Heat shock $70 \mathrm{kDa}$ protein 4} & hsp70 & TGAACAGCGCTATGAACCAG & 117 \\
\hline & & TCATGATGGGGTTACAAGCA & \\
\hline \multirow[t]{2}{*}{ Heat shock 90 kDa beta } & hsp90ba & CGAGGAGCACTACAACGACA & 181 \\
\hline & & GTCCTGCTTCTCCTTCATGC & \\
\hline \multirow[t]{2}{*}{ Stress-induced-phosphoprotein 1 (Hsp70/Hsp90-organizing) } & stip1 & CCGATGTCCTGAAGAGGTGT & 141 \\
\hline & & TCATGGCTAAGGGGTAGTCG & \\
\hline \multirow[t]{2}{*}{ Follistatin } & fst & ACCTGGAAAGGACCAGTGTG & 117 \\
\hline & & GCACTITCCCTGGTACTGGA & \\
\hline \multirow[t]{2}{*}{ Formin-binding protein 4} & fnbp4 & GCCTGACCTCCACAGATGTT & 100 \\
\hline & & CAACACGGACATCTTCATCG & \\
\hline \multirow[t]{2}{*}{ Keratin 12} & krt12 & GCCAAGACTGACCTGACCAT & 188 \\
\hline & & GCCTCGTAGTGTTCCCTGAC & \\
\hline \multirow[t]{2}{*}{ Ikaros } & $i k z f$ & ATGATCTCCGGGTCTGTGAG & 165 \\
\hline & & ACACTTGAGCTTTCCGTCGT & \\
\hline \multicolumn{4}{|l|}{ Reference genes } \\
\hline \multirow[t]{2}{*}{ ATP synthase subunit s mitochondrial } & ATP5s & AACAGGGTGGACTATGAGAGGA & 114 \\
\hline & & GTGATGCCAGCGTTCAAA & \\
\hline \multirow[t]{2}{*}{ Eukaryotic translation initiation factor 3 subunit 3 gamma $40 \mathrm{kDa}$ isoform CRA b } & elF3 & AGGACGACGCAGACTTTGAC & 121 \\
\hline & & ACGAAGGAGCCGTAGAAGGT & \\
\hline \multirow[t]{2}{*}{ Tetratricopeptide repeat protein $39 \mathrm{C}$} & $\operatorname{tpr} 39$ & GAAACGGGCTGAGAGACTGA & 63 \\
\hline & & ATGACACCCAGGAAGCAGAG & \\
\hline \multirow[t]{2}{*}{ Dehydrogenase/reductase SDR family member 11} & dhrs 11 & GGAGACAGAGTTTGCGTTCC & 128 \\
\hline & & GAGGGGCACTGAGGACATAA & \\
\hline \multirow[t]{2}{*}{ Ubiquitin } & ubi & GGCCGCAAAGATGCAGAT & 69 \\
\hline & & CTGGGCTCGACCTCAAGAGT & \\
\hline
\end{tabular}


transcripts from Ensembl and Unigene which were annotated by functional categories of GO and pathways of KEGG using bioinformatics package STARS $[78,86]$. The genes were assigned to the orthology groups of OrthoDB [87]. Three and two biological replicates of the respectively three first and two last stages were analyzed in a total of 13 microarrays. Reference RNA was prepared by pooling equal amounts of RNA from pyloric caeca, liver, muscle, brain and male and female gonad to identify genes with increased expression in oocytes and embryos or developmentally regulated genes. The common reference design also made possible comparison between stages and finding of stage-specific genes. RNA amplification, labeling and fragmentation were performed using TwoColour Quick Amp Labeling Kit and Gene Expression Hybridization kit following the manufacturer's instructions (Agilent Technologies). The input of total RNA used in each reaction was $100 \mathrm{ng}$. Individual samples were compared to the common reference; assignment of fluorescent labels ( $\mathrm{Cy} 5$ and $\mathrm{Cy} 3)$ was changed in each hybridization performed at $65^{\circ} \mathrm{C}$ at the rotation speed of $10 \mathrm{rpm}$ for 17 hours in the oven (Agilent Technologies). The slides were washed with Gene Expression Wash Buffers 1 and 2 as described by the manufacturer and scanning was performed at $5 \mu \mathrm{m}$ resolution using a GenePix Personal 4100A scanner (Molecular Devices, Sunnyvale, CA, USA). The laser power was manually adjusted and the "auto PMT" was enabled to adjust PMT for each channel such that less than $0.1 \%$ of features were saturated and that the mean intensity ratio of the Cy3 and Cy5 signals was close to one. Nofima's bioinformatic package STARS was used for data processing and mining. After filtration of low quality spots flagged by FE, lowess normalization of $\log _{2}$-expression ratios (ER) was performed. Results for the two last developmental stages were highly similar and these samples were therefore merged and denoted as SGM (segmentation). Features that passed quality control in all samples of at least one stage and showed over 2-fold difference from reference were selected (Additional file 1). Further, the features were assigned to groups with different temporal profiles (Figure 1) according to criteria presented in Table 1 with minor manual editing. Data were submitted to GEO Omnibus (GSE58392).

\section{Quantitative real-time RT-PCR}

Eight genes were selected for qPCR analyses based on the results of microarray analyses (Table 2). Gene expression measured by real-time qPCR was performed on the same samples that were used for microarray analysis. Primers were designed with Primer3 software and synthesized by Life Technologies. The amplicon lengths were set to be between 60 and 200 base pairs. The cDNA synthesis was performed on $1.5 \mu \mathrm{g}$ total RNA using the
SuperScript ${ }^{\circ}$ VILO $^{\text {tw }}$ cDNA Synthesis Kit (Life Technologies) in a $20 \mu \mathrm{l}$ reaction system according to the manufacturer's protocol. The specificity of PCR amplification was confirmed with melting curve analysis. Efficiency was checked from tenfold serial dilutions of cDNA for each primer pair. A $2 \times \mathrm{SYBR}^{\circ}$ Green PCR Mastermix (Roche Diagnostics, Mannheim, Germany), $0.8 \mathrm{mM}$ of each primer, and $4 \mu$ of 1:10 diluted cDNA template were mixed in $12 \mu \mathrm{l}$ reaction volumes. PCR was performed in duplicates in 96-well optical plates on Light Cycler 480 (Roche Diagnostics, Mannheim, Germany) under the following conditions: $95^{\circ} \mathrm{C}$ for $5 \mathrm{~min}$ (pre-incubation), $95^{\circ} \mathrm{C}$ for $5 \mathrm{~s}$, $60^{\circ} \mathrm{C}$ for $15 \mathrm{~s}, 72^{\circ} \mathrm{C}$ for $15 \mathrm{~s}$ (amplification), followed by $95^{\circ} \mathrm{C}$ for $5 \mathrm{~s}$ and $65^{\circ} \mathrm{C}$ for $1 \mathrm{~min}$ (melting curve). 45 amplification cycles were performed. We tested some of the commonly used reference genes and they all showed substantial variation in expression levels between fertilized oocytes and somitogenesis in agreement with other embryonic studies of Atlantic cod [88]. Hence, we selected six other candidate genes that showed stable expression on microarray throughout the development and tested them as reference genes. Finally, the combination of five most stable genes (Table 2) was used for normalization and the data are given as $-\mathrm{ddCt}$ values.

\section{Additional file}

Additional file 1: Data are log2-Expression Ratio to reference.

Column S - groups (prezygotic and zygotic), column $\mathrm{T}$ - subgroups defined by the temporal profiles.

\section{Competing interests}

The authors declare that they have no competing interests.

\section{Author's contributions}

$\varnothing A$ designed the experiment. AŠ performed the gene expression analyses. AK analyzed the data and together with AŠ drafted the manuscript. All authors read, contributed to and approved the final manuscript.

\section{Acknowledgements}

We would like to thank the Norwegian Research Council (project no: 190371) for providing necessary financial support.

\section{Author details}

${ }^{1}$ Nofima, Osloveien 1, N-1432 Ås, Norway. ${ }^{2}$ Department of Animal and Aquaculture Sciences, Norwegian University of Life Sciences, N-1432 Ås, Norway.

Received: 3 February 2014 Accepted: 9 July 2014

Published: 14 July 2014

\section{References}

1. Lubzens E, Young G, Bobe J, Cerdà J: Oogenesis in teleosts: how fish eggs are formed. Gen Comp Endocrinol 2010, 165:367-389.

2. DePamphilis ML, Kaneko KJ, Vassilev A: Activation Of Zygotic gene expression in mammals. In Gene expression at the beginning of animal development, advances in developmental biology and biochemistry series, Volume 12. Edited by M.L. D, PM W. Netherlands: Elsevier Science; 2002:55-84.

3. Schier AF: The maternal-zygotic transition: death and birth of RNAs. Science 2007, 316:406-407. 
4. Mtango NR, Potireddy S, Latham KE: Oocyte quality and maternal control of development. Int Rev Cell Mol Biol 2008, 268:223-290.

5. Fischer BE, Wasbrough E, Meadows LA, Randlet O, Dorus S, Karr TL, Russell S: Conserved properties of Drosophila and human spermatozoal mRNA repertoires. Proc Biol Sci 2012, 279:2636-2644.

6. Martins RP, Krawetz SA: RNA in human sperm. Asian J Androl 2005, 7:115-120.

7. Rudel D, Sommer RJ: The evolution of developmental mechanisms. Dev Biol 2003, 264:15-37

8. Lawrence PA, Levine M: Mosaic and regulative development: two faces of one coin. Curr Biol 2006, 16:R236-R239.

9. De Renzis S, Elemento O, Tavazoie S, Wieschaus EF: Unmasking activation of the zygotic genome using chromosomal deletions in the Drosophila embryo. PLoS Biol 2007, 5:e117.

10. Mathavan S, Lee SG, Mak A, Miller LD, Murthy KR, Govindarajan KR, Tong $Y$, Wu YL, Lam SH, Yang H, Ruan Y, Korzh V, Gong Z, Liu ET, Lufkin T: Transcriptome analysis of zebrafish embryogenesis using microarrays. PLoS Genet 2005, 1:260-276.

11. Wieschaus E: Embryonic Transcription and the Control of Developmental Pathways. Genetics 1996, 142:5-10.

12. Flach $\mathrm{G}$, Johnson $M H$, Braude $P R$, Taylor RA, Bolton VN: The transition from maternal to embryonic control in the 2-cell mouse embryo. Embo J 1982, 1:681-686.

13. Braude $P$, Bolton $V$, Moore $S$ : Human gene expression first occurs between the four- and eight-cell stages of preimplantation development. Nature 1988, 332:459-461.

14. Hoffert KA, Anderson GB, Wildt DE, Roth TL: Transition from maternal to embryonic control of development in IVM/IVF domestic cat embryos. Mol Reprod Dev 1997, 48:208-215.

15. Frei RE, Schultz GA, Church RB: Qualitative and quantitative changes in protein synthesis occur at the 8-16-cell stage of embryogenesis in the cow. J Reprod Fertil 1989, 86:637-641.

16. Kraeussling M, Wagner TU, Schartl M: Highly asynchronous and asymmetric cleavage divisions accompany early transcriptional activity in pre-blastula medaka embryos. PLoS One 2011, 6:7.

17. Kimmel CB, Ballard WW, Kimmel SR, Ullmann B, Schilling TF: Stages of embryonic development of the zebrafish. Dev Dyn 1995, 203:253-310.

18. Howe JA, Newport JW: A developmental timer regulates degradation of cyclin E1 at the midblastula transition during Xenopus embryogenesis. Proc Natl Acad Sci U S A 1996, 93:2060-2064.

19. Sibon OC, Stevenson VA, Theurkauf WE: DNA-replication checkpoint control at the Drosophila midblastula transition. Nature 1997, 388:93-97.

20. Tadros W, Lipshitz HD: The maternal-to-zygotic transition: a play in two acts. Development 2009, 136:3033-3042.

21. Solnica-Krezel $\mathrm{L}$ : Conserved patterns of cell movements during vertebrate gastrulation. Curr Biol 2005, 15:R213-R228.

22. Stern CD: Vertebrate gastrulation. Curr Opin Genet Dev 1992, 2:556-561.

23. Seeger M, Tear G, Ferres-Marco D, Goodman CS: Mutations affecting growth cone guidance in Drosophila: genes necessary for guidance toward or away from the midline. Neuron 1993, 10:409-426.

24. Wright AP, Fox AN, Johnson KG, Zinn K: Systematic screening of Drosophila deficiency mutations for embryonic phenotypes and orphan receptor ligands. PLOS One 2010, 5:0012288.

25. Nusslein-Volhard C, Wieschaus E: Mutations affecting segment number and polarity in Drosophila. Nature 1980, 287:795-801.

26. Amsterdam A, Hopkins N: Mutagenesis strategies in zebrafish for identifying genes involved in development and disease. Trends Genet 2006, 22:473-478.

27. Haffter $P$, Granato M, Brand M, Mullins MC, Hammerschmidt M, Kane DA, Odenthal J, van Eeden FJ, Jiang YJ, Heisenberg CP, Kelsh RN, Furutani-Seiki M, Vogelsang E, Beuchle D, Schach U, Fabian C, Nüsslein-Volhard C: The identification of genes with unique and essential functions in the development of the zebrafish, Danio rerio. Development 1996, 123:1-36.

28. Alestrom P, Holter $\mathrm{J}$, Nourizadeh-Lillabadi R: Zebrafish in functional genomics and aquatic biomedicine. Trends Biotechnol 2006, 24:15-21.

29. Star B, Nederbragt AJ, Jentoft S, Grimholt U, Malmstrom M, Gregers TF, Rounge TB, Paulsen J, Solbakken MH, Sharma A, Wetten OF, Lanzén A, Winer R, Knight J, Vogel JH, Aken B, Andersen O, Lagesen K, ToomingKlunderud A, Edvardsen RB, Tina KG, Espelund M, Nepal C, Previti C, Karlsen BO, Moum T, Skage M, Berg PR, Gjøen T, Kuhl H, et al: The genome sequence of Atlantic cod reveals a unique immune system. Nature 2011, 477:207-210.

30. Drivenes O, Taranger GL, Edvardsen RB: Gene expression profiling of Atlantic cod (Gadus morhua) embryogenesis using microarray. Mar Biotechnol 2012, 14:167-176.

31. Hall TE, Smith P, Johnston IA: Stages of embryonic development in the Atlantic cod Gadus morhua. J Morphol 2004, 259:255-270.

32. Wickramasinghe D, Becker S, Ernst MK, Resnick JL, Centanni JM, Tessarollo L, Grabel LB, Donovan PJ: Two CDC25 homologues are differentially expressed during mouse development. Development 1995, 121:2047-2056.

33. Edgar BA, Datar SA: Zygotic degradation of two maternal Cdc25 mRNAs terminates Drosophila's early cell cycle program. Genes Dev 1996, 10:1966-1977.

34. Tourret J, McKeon F: Tyrosine kinases wee1 and mik1 as effectors of DNA replication checkpoint control. Prog Cell Cycle Res 1996, 2:91-97.

35. Hung LY, Tang CJ, Tang TK: Protein 4.1 R-135 interacts with a novel centrosomal protein (CPAP) which is associated with the gamma-tubulin complex. Mol Cell Biol 2000, 20:7813-7825

36. Roche KC, Wiechens N, Owen-Hughes T, Perkins ND: The FHA domain protein SNIP1 is a regulator of the cell cycle and cyclin D1 expression. Oncogene 2004, 23:8185-8195.

37. Krishnan S, Horowitz S, Trievel RC: Structure and function of histone H3 lysine 9 methyltransferases and demethylases. Chembiochem 2011, 12:254-263.

38. Morris KV: RNA and the Regulation of Gene Expression: A Hidden Layer of Complexity. Norfolk: Caister Academic Press; 2008.

39. Hanai K, Furuhashi H, Yamamoto T, Akasaka K, Hirose S: RSF governs silent chromatin formation via histone H2Av replacement. PLOS Genet 2008, 4:1000011.

40. Sinha A, Faller DV, Denis GV: Bromodomain analysis of Brd2-dependent transcriptional activation of cyclin A. Biochem J 2005, 387:257-269.

41. Denis GV, McComb ME, Faller DV, Sinha A, Romesser PB, Costello CE: Identification of transcription complexes that contain the double bromodomain protein $\mathrm{Brd} 2$ and chromatin remodeling machines. J Proteome Res 2006, 5:502-511.

42. Vassetzky $Y$, Hair A, Mechali M: Rearrangement of chromatin domains during development in Xenopus. Genes Dev 2000, 14:1541-1552.

43. Schlingensiepen K-H, Wollnik F, Kunst M, Schlingensiepen R, Herdegen T, Brysch W: The role of Jun transcription factor expression and phosphorylation in neuronal differentiation, neuronal cell death, and plastic adaptationsin vivo. Cell Mol Neurobiol 1994, 14:487-505.

44. Jacobs-Helber SM, Abutin RM, Tian C, Bondurant M, Wickrema A, Sawyer ST: Role of JunB in erythroid differentiation. J Biol Chem 2002, 277:4859-4866.

45. Bamforth SD, Braganca J, Eloranta JJ, Murdoch JN, Marques FI, Kranc KR, Farza H, Henderson DJ, Hurst HC, Bhattacharya S: Cardiac malformations, adrenal agenesis, neural crest defects and exencephaly in mice lacking Cited2, a new Tfap2 co-activator. Nat Genet 2001, 29:469-474.

46. Torgersen JS, Takle H, Andersen $\varnothing$ : Differential spatial expression of mef2 paralogs during cardiac development in Atlantic cod (Gadus morhua). Comp Biochem Physiol B Biochem Mol Biol 2011, 158:181-187.

47. Kageyama R, Ohtsuka T, Kobayashi T: The Hes gene family: repressors and oscillators that orchestrate embryogenesis. Development 2007, 134:1243-1251.

48. Stafford DA, Monica SD, Harland RM: Follistatin interacts with Noggin in the development of the axial skeleton. Mech Dev 2014, 134:78-85.

49. Schweitzer J, Gimnopoulos D, Lieberoth BC, Pogoda HM, Feldner J, Ebert A, Schachner M, Becker T, Becker CG: Contactin1a expression is associated with oligodendrocyte differentiation and axonal regeneration in the central nervous system of zebrafish. Mol Cell Neurosci 2007, 35:194-207.

50. Shimoda Y, Watanabe K: Contactins: emerging key roles in the development and function of the nervous system. Cell Adh Migr 2009, 3:64-70

51. Racher H, Hansen D: PUF-8, a Pumilio homolog, inhibits the proliferative fate in the Caenorhabditis elegans germline. G3 2012, 2:1197-1205.

52. Thiery JP, Acloque H, Huang RY, Nieto MA: Epithelial-mesenchymal transitions in development and disease. Cell 2009, 139:871-890.

53. Wuebben EL, Mallanna SK, Cox JL, Rizzino A: Musashi2 is required for the self-renewal and pluripotency of embryonic stem cells. PLoS One 2012, 7:4.

54. Bree RT, McLoughlin S, Jin SW, McMeel OM, Stainier DY, Grealy M, Byrnes L: nanor, a novel zygotic gene, is expressed initially at the midblastula transition in zebrafish. Biochem Biophys Res Commun 2005, 333:722-728. 
55. Landthaler M, Yalcin A, Tuschl T: The human DiGeorge syndrome critical region gene 8 and Its $D$. melanogaster homolog are required for miRNA biogenesis. Curr Biol 2004, 14:2162-2167.

56. Giraldez AJ, Mishima Y, Rihel J, Grocock RJ, Van Dongen S, Inoue K, Enright AJ, Schier AF: Zebrafish MiR-430 promotes deadenylation and clearance of maternal mRNAs. Science 2006, 312:75-79.

57. Aanes $H$, Winata $C L$, Lin CH, Chen JP, Srinivasan KG, Lee SG, Lim AY, Hajan HS, Collas P, Bourque G, Gong Z, Korzh V, Aleström P, Mathavan S: Zebrafish mRNA sequencing deciphers novelties in transcriptome dynamics during maternal to zygotic transition. Genome Res 2011, 21:1328-1338.

58. Avilion AA, Nicolis SK, Pevny LH, Perez L, Vivian N, Lovell-Badge R: Multipotent cell lineages in early mouse development depend on SOX2 function. Genes Dev 2003, 17:126-140.

59. Bonnet A, Bevilacqua C, Benne F, Bodin L, Cotinot C, Liaubet L, Sancristobal M, Sarry J, Terenina E, Martin P, Tosser-Klopp G, Mandon-Pepin B: Transcriptome profiling of sheep granulosa cells and oocytes during early follicular development obtained by laser capture microdissection. BMC Genomics 2011, 12:1471-2164.

60. Shen-Orr SS, Pilpel Y, Hunter CP: Composition and regulation of maternal and zygotic transcriptomes reflects species-specific reproductive mode. Genome Biol 2010, 11:2010-2011.

61. Gilbert I, Bissonnette N, Boissonneault G, Vallee M, Robert C: A molecular analysis of the population of mRNA in bovine spermatozoa. Reproduction 2007, 133:1073-1086.

62. Ostermeier GC, Miller D, Huntriss JD, Diamond MP, Krawetz SA: Reproductive biology: delivering spermatozoan RNA to the oocyte. Nature 2004, 429:154.

63. Harvey SA, Sealy I, Kettleborough R, Fenyes F, White R, Stemple D, Smith JC: Identification of the zebrafish maternal and paternal transcriptomes. Development 2013, 140:2703-2710.

64. Ellingsen T, Strand C, Monsen E, Bogwald J, Dalmo RA: The ontogeny of complement component C3 in the spotted wolffish (Anarhichas minor Olafsen). Fish Shellfish Immunol 2005, 18:351-358.

65. Lovoll M, Kilvik T, Boshra H, Bogwald J, Sunyer JO, Dalmo RA: Maternal transfer of complement components C3-1, C3-3, C3-4, C4, C5, C7, Bf, and Df to offspring in rainbow trout (Oncorhynchus mykiss). Immunogenetics 2006, 58:168-179.

66. Wang Z, Zhang S, Wang G, An Y: Complement activity in the egg cytosol of zebrafish Danio rerio: evidence for the defense role of maternal complement components. PLoS One 2008, 3:0001463.

67. Wang Z, Zhang S, Tong Z, Li L, Wang G: Maternal transfer and protective role of the alternative complement components in zebrafish Danio rerio. PLoS One 2009, 4:18.

68. Seppola M, Johnsen H, Mennen S, Myrnes B, Tveiten H: Maternal transfer and transcriptional onset of immune genes during ontogenesis in Atlantic cod. Dev Comp Immunol 2009, 33:1205-1211.

69. Swain P, Nayak SK: Role of maternally derived immunity in fish. Fish Shellfish Immunol 2009, 27:89-99.

70. Warga RM, Kane DA: A role for $\mathrm{N}$-cadherin in mesodermal morphogenesis during gastrulation. Dev Biol 2007, 310:211-225.

71. Gumbiner BM: Regulation of cadherin-mediated adhesion in morphogenesis. Nat Rev Mol Cell Biol 2005, 6:622-634.

72. Kishigami S, Mishina Y: BMP signaling and early embryonic patterning. Cytokine Growth Factor Rev 2005, 16:265-278.

73. Hayward P, Kalmar T, Arias AM: Wnt/Notch signalling and information processing during development. Development 2008, 135:411-424.

74. Hayflick JS, Wolfgang WJ, Forte MA, Thomas G: A unique Kex2-like endoprotease from Drosophila melanogaster is expressed in the central nervous system during early embryogenesis. J Neurosci 1992, 12:705-717.

75. Cadieux B, Chitramuthu BP, Baranowski D, Bennett HP: The zebrafish progranulin gene family and antisense transcripts. BMC Genomics 2005, 6:156.

76. Masi T, Johnson AD: Axbrn-1: a maternal transcript encodes a POU transcription factor that is later expressed in the developing central nervous system of axolotl embryos. Dev Genes Evol 2001, 211:449-452.

77. Krasnov A, Timmerhaus G, Schiøtz BL, Torgersen J, Afanasyev S, lliev D, Jørgensen J, Takle H, Jørgensen SM: Genomic survey of early responses to viruses in Atlantic salmon, Salmo salar L. Mol Immunol 2011, 49:163-174.

78. Krasnov A, Kileng O, Skugor S, Jorgensen SM, Afanasyev S, Timmerhaus G, Sommer Al, Jensen I: Genomic analysis of the host response to nervous necrosis virus in Atlantic cod (Gadus morhua) brain. Mol Immunol 2013, 54:443-452.

79. Alizadeh Z, Kageyama S, Aoki F: Degradation of maternal mRNA in mouse embryos: selective degradation of specific mRNAs after fertilization. Mol Reprod Dev 2005, 72:281-290.

80. Ho L, Crabtree GR: Chromatin remodelling during development. Nature 2010, 463:474-484

81. Skjaerven KH, Olsvik PA, Finn RN, Holen E, Hamre K: Ontogenetic expression of maternal and zygotic genes in Atlantic cod embryos under ambient and thermally stressed conditions. Comp Biochem Physiol A Mol Integr Physiol 2011, 159:196-205.

82. Felsenfeld G: Chromatin unfolds. Cell 1996, 86:13-19.

83. Pearson JC, Lemons D, McGinnis W: Modulating Hox gene functions during animal body patterning. Nat Rev Genet 2005, 6:893-904.

84. Wellik DM: Hox genes and vertebrate axial pattern. Curr Top Dev Biol 2009, 88:257-278.

85. Gorodilov YN, Terjesen B, Krasnov A, Takle H: Description of Embryogenesis of Atlantic Cod Gadus morhua. Open Mar Biol J 2008, 2:43-53.

86. Krasnov A, Timmerhaus G, Afanasyev S, Jorgensen SM: Development and assessment of oligonucleotide microarrays for Atlantic salmon (Salmo salar L.). Comp Biochem Physiol Part D Genomics Proteomics 2011, 6:31-38.

87. Waterhouse RM, Tegenfeldt F, Li J, Zdobnov EM, Kriventseva EV: OrthoDB: a hierarchical catalog of animal, fungal and bacterial orthologs. Nucleic Acids Res 2013, 41:24.

88. Johnsen $\mathrm{H}$, Andersen $\varnothing$ : Sex dimorphic expression of five dmrt genes identified in the Atlantic cod genome. The fish-specific dmrt2b diverged from dmrt2a before the fish whole-genome duplication. Gene 2012, 505:221-232.

doi:10.1186/1471-2164-15-594

Cite this article as: Škugor et al:: Genome-wide microarray analysis of Atlantic cod (Gadus morhua) oocyte and embryo. BMC Genomics 2014 15:594.

\section{Submit your next manuscript to BioMed Central and take full advantage of:}

- Convenient online submission

- Thorough peer review

- No space constraints or color figure charges

- Immediate publication on acceptance

- Inclusion in PubMed, CAS, Scopus and Google Scholar

- Research which is freely available for redistribution

Submit your manuscript at www.biomedcentral.com/submit
C) Biomed Central 